International Journal of Oceanography and Hydrobiology Volume 50, No. 4, December 2021

\title{
Empirical approach to risk management strategies of Mediterranean mussel farmers in Greece
}

by

\author{
John A. Theodorou*, loannis Tzovenis, \\ George Katselis
}

\section{DOI: 10.2478/oandhs-2021-0039 \\ Category: Original research paper \\ Received: March 27, 2021 \\ Accepted: June 21, 2021}

\section{Department of Animal Production, Fisheries \& Aquaculture, Patras University, Nea Ktiria Gr 30200, Mesolonghi, Greece \\ Laboratory of Ecology and Systematics, Biology Department, University of Athens, Panepistimioupolis, Zografou 15784, Greece}

\begin{abstract}
Risk perception and risk responses of Greek mussel farmers are important for understanding their risk behavior and the likely success of different risk mitigation strategies. This allows policy makers and actuarial companies to decide what risk management products to offer to address specific types of risks.

Results from an empirical survey showed that ex-farm prices and health/disability status of farmers are perceived as the most important sources of risk.

Risk management decisions were strongly influenced by the attitudes of mussel farmers rather than their socioeconomic status or perception of risk sources.

Financial reserves and an alternative source of stable income are both preferred by mussel farmers as risk management strategies, while optimizing farm management to produce at the lowest possible cost is commonly practiced to eliminate losses. Farmers recommend that for certain types of risks that lead to total losses, e.g. anoxia, tsunamis, harmful algal blooms (HABs), insurance contracts should be provided by the public sector, as in similar situations in agriculture. For other needs, customized insurance contracts should be provided by the actuarial market.
\end{abstract}

Key words: Mediterranean mussels, aquaculture, risk management, insurance policies

* Corresponding author: jtheo@upatras.gr 


\section{Introduction}

The growth and production of commercial aquaculture, a relatively new source of primary food production, faces potential threats similar to those of terrestrial agriculture. To support traditional land-based farmers, extensive theoretical as well as practical risk-management research and advice is available (e.g. Meuwissen et al. 2001; Anderson 2003; Hardaker et al. 2004, 2015; Huirne et al. 2000, 2007; van Winsen et al. 2013, 2016; Wauters et al. 2014). By comparison, there is lack of empirical knowledge and practical risk mitigation solutions for aquaculture operations (Theodorou \& Tzovenis 2004; Bergfjord 2009, 2013; Le \& Cheong 2010; Ahsan 2011; Zagmutt et al. 2013; Joffre et al. 2019). Moreover, as aquaculture is relatively more diverse in terms of species cultured (e.g. finfish, shellfish, seaweeds) and of environments (freshwater, marine), the range of hazards and perceived risks in aquaculture are more varied and need to be assessed for their specificity (Bondad-Reantaso et al. 2008; Joffre et al. 2018a,b; Guillotreau et al. 2017).

Bergfjord $(2009,2013)$ suggested that both the attitudes of Norwegian salmon farmers toward risk and their perception of risk need be taken into account as the behavioral impact in the risk-based decision-making studies of aquaculture have been poorly documented. Similarly, Le and Cheong (2010) empirically examined risk perception and management strategies in the production activities of catfish farmers in Vietnam. Ahsan (2011) showed how the risk perception of Bangladeshi coastal shrimp farmers shapes their risk management strategies based on Van Raaij's (1981) framework model. Van Raaij (1981) explained how the economic behavior (risk management strategies) of individual farmers is an outcome of their perception determined by the economic situation (production, market, legislation, national and global economy) and their personal socioeconomic characteristics (age, education, gender, farm size, occupation).

Recently, in order to address the gap in knowledge about bivalve aquaculture in Europe, attempts have been made by several researchers to deal with risks in different shellfish industries, such as mussels in Denmark (Ahsan \& Roth 2010) or oysters in France (Le Grel \& Le Bihan 2009; Le Bihan et al. 2013, 2020; Guillotreau et al. 2021). They included quantitative studies on the influence of motivation and risk perception, especially those that address risk management in the bivalve shellfish sector, suggesting risk policies.

As Mediterranean mussel farming in Greece is becoming a growing industry, there is a high demand for would-be farmers to be able to assess the risks involved in starting the business (Theodorou et al. 2014; 2015). To achieve sustainability, the viability strategies of mussel aquaculture businesses have to incorporate risk management strategies at the farm and sector level (Bondad-Reantaso et al. 2008; Theodorou \& Tzovenis 2017). The following types of risk sources were defined as related or associated with the conditions of sale of produce: i) production dependent (e.g. diseases), ii) production independent (e.g. pollution, predators, weather, $H A B s$ ), iii) commercialization (e.g. price fluctuations, transportation), iv) third party risk (e.g. environmental impact of aquaculture) according to Theodorou \& Tzovenis (2004).

The purpose of this study is to provide empirical insights into the risk perception of Greek mussel farmers, risk management approaches, their motivations and how social and economic characteristics relate to risk strategies of Greek mussel farms. To this end, data from a survey on Mediterranean mussel farmers in Greece were analyzed. This information is critical for assessing feasible options for risk mitigation, including both public and private market options (Joffre et al. 2019). Knowledge of what types of markets are required by farmers can help policy makers and private actuarial firms to decide what risk management products to provide for specific types of risks (Theodorou \& Tzovenis 2021).

The present study of the economic risk behavior of Greek mussel farmers was based on the principles of van Raaij's (1981) descriptive model, where the perceived operating environment determines economic behavior, considering also the impact on their personal welfare according to Lien et al. (2005).

\section{Materials and methods}

\subsection{Survey}

Questionnaires were distributed to all Greek mussel farmers between November 2008 and February 2009 and completed under the guidance of advisers during personal interviews and site visits. The survey targeted the whole industry, with an estimated total production capacity of 45403 tons shared by 523 operating farms. Prior to its large scale use, the questionnaire was extensively tested for the risk terminology used. This aimed at structuring the questions and eliminating linguistic uncertainty. The questions about "sources of risks" and "risk 
management strategies" were based on the opinion of four mussel farming experts, and pre-tested on five farmers with a strong educational background and experience profiles before being presented to the respondents.

\subsection{Data Collection}

The research design and the structure and drafting of the questionnaire were based on the empirical study by Meuwissen et al. (2001) carried out for livestock producers in the Netherlands. Seven questions refer to the "socioeconomic features of farmers" (farm area, production, full-time/part-time occupation and respondents' age, education and work experience). To understand "mussel farmers' perception of risk attitudes", five questions were used (willingness to take risk in production, in marketing, in farming in general; financial issues - more than my colleagues and whether "I am willing to take more risks than other farmers"), the last of which "willingness to take risks in farming in general" was included as a consistency check elsewhere in the questionnaire. Since all statements measure attitudes toward risks relative to other farmers, the term "relative risk attitude" was used according to Patrick and Musser (1997) and Meuwissen et al. (2001).

Thirty-three questions refer to the "sources of risks" and cover "in-farm production risk" (five questions: IDs 1-5), "technological risks" (three questions: IDs 6-8), "ex-farm economic risks" (three questions: IDs 9-11), "ex-farm production risks" (six questions: IDs 12-17), "customer perception risks" (five questions: IDs 18-22), "ex-farm risks related to government support" (four questions: IDs 23-26), "financial risks" (three questions: IDs 27-29) and "risks related to family situation" (four questions: IDs 30-33).

Fifteen questions refer to "risk management strategies" and cover "in-farm investments" (five questions: IDs 1-6), "ex-farm investments" (two questions: IDs 7-10), "insurance" (three questions: IDs 11-13) and "selling price" (two questions: IDs 14-15).

Finally, three questions (What risks do you consider manageable? For what types of risks would you like to purchase insurance? What type of risk could be covered by public/government support?) constitute the open-ended questions of the questionnaire. The answers were then categorized and presented as percentages of the responses.

The questions under respondents' perception of their risk attitude, sources of risks and risk management strategies were to be answered on a Likert type scale of 1 to 5: 1 (disagree) to 5 (agree) for respondents perception of their risk attitude; 1 (no impact) to 5 (very high impact) for sources of risks; and 1 (not relevant) to 5 (very relevant) for risk management strategies.

\subsection{Data Analysis}

Data analysis starts with descriptive statistics of questionnaire responses, followed by principal component analysis to reduce the large number of examined variables to a smaller representative group, thus simplifying the evaluation process.

The adequacy of the available sample was checked using the Kaiser-Meyer-Olkin (KMO) test and Barlett's test of sphericity. Orthogonal varimax rotation was used to ensure (extract) the maximum independence between factors. Factors' scores were used for subsequent multivariate regression analysis to determine their impact on risk perception of mussel farmers and their risk management strategies.

To assess the relative importance of each question under the categories respondents' perception of their risk attitude, sources of risk and risk management strategies, responses were ranked by their mean (Mi) in descending order: $\mathrm{Mi} \geq 4=$ important; $3 \leq \mathrm{Mi}<4=$ high moderate; $2 \leq \mathrm{Mi}<3$ = low moderate; $\mathrm{Mi}<2=$ low.

In order to reduce the number of variables and possible collinearity among the variables, factor analysis (FA) was applied on normalized and standardized data for variables of each category: (a) socioeconomic features of the farm and respondent, respondents' perception of their risk attitude (SER), (b) sources of risks (SR) and (c) risk management strategies (RMS).

Factor analysis (FA) is a multivariate analysis method that aims at explaining the correlation between a large set of variables in terms of a small number of underlying independent factors. Principal factor analysis was used to extract factor loadings.

Each principal factor (PFi) represents a distinct cluster of intercorrelated variables. Thus, two variables of high magnitude in the same factor are highly correlated. The varimax rotation method (orthogonal rotation) was used to make each factor uniquely defined as a distinct cluster of intercorrelated variables. Factor loadings indicate the weight of each variable on its corresponding axis, while per factor scores (SPFi) are the linear result of initial variables with respect to this factor. The sign of the loading indicates the direction of the relationship between the factor and the variable as well as between intercorrelated variables in each PFi. The variation incorporated in each factor is expressed by its eigenvalue. Factors with eigenvalues $>1$ (cut-off point for extracted factors) account for more variance than original variables of standardized data (Hair et al. 
1998). The resulting data sets of the factor analysis FA (per factor scores: SPFi) on SER (socioeconomic \& risk attitude), SR (risk sources) and RMS (risk management strategy) variables were SER factors, SR factors and RMS factors, respectively.

Multivariate analysis of variance (MANOVA) and post hoc Tukey HSD test were applied to identify significant differences in SER, SR and RMS scores in relation to the legal status of enterprises and their culture systems.

Path analysis is an extension of multiple regression analysis, which is regarded as a special case of structural equation modeling. The path model aims to overcome potential shortcomings in conventional models, e.g. linear regressions, by transforming causal effects into direct and indirect effects.

In this study, path analysis was applied to estimate the magnitude and significance of hypothesized direct effects of SER and SR on RMS and indirect effects of SER through SR on RMS (Fig. 1). Path coefficients were standardized regression coefficients in a system of linear regression equations (Wrigth 1934):

$$
\begin{gathered}
S R_{k}=B_{k . i} S E R_{i}+e_{k^{\prime}} R_{k}^{2} \\
\text { and } \\
R M S_{j}=B_{j . i} S E R_{i}+B_{j . k} S R_{k}+e_{j^{\prime}} R_{j}^{2}
\end{gathered}
$$

where $i, k$ and $j$ are the SER factor, the SR factor and the RMS factor, respectively, B's are standardized regression coefficients, e is the random error term and $R^{2}$ is the determination coefficient estimated by the least squares regression techniques (multi-regression analysis - MGR). $R^{2}$ expresses the proportion of variance in a given dependent variable explained by an independent variable to the total variance of all

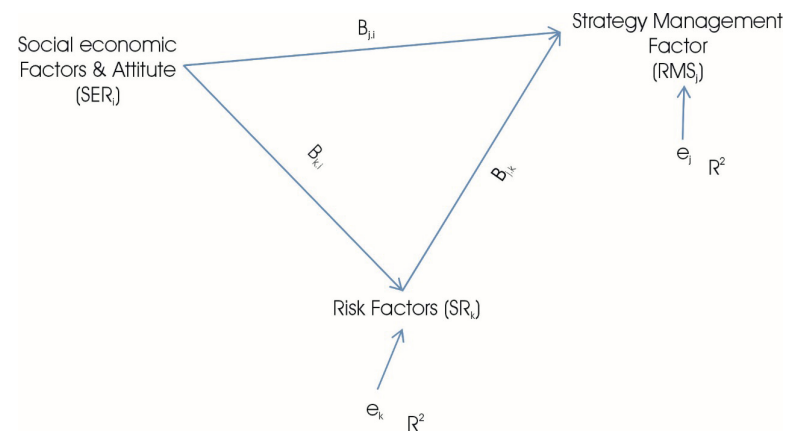

Figure 1

Path analysis framework for risk management strategies in relation to socioeconomic and risk factors of Greek mussel farmers

dependent variables. The $B$ coefficient is defined as the ratio of the standard deviation of the effect due to a given cause to the total standard deviation of the effect. For RMS, the direct effects are $B_{i, j}$ and $B_{j, k}\left(1-B_{k j}\right)$ and the indirect effect is $\left(B_{k . j}\right)\left(B_{j . k}\right)$, while for SR only direct effects $\left(B_{k j}\right)$ are recorded. The total effect of each SER on each RMS through various SRs is the sum of direct and indirect effects of the involved variables (SER and SRs).

Significant factors used in the final model were selected through the backward stepwise variable selection method (F-to-remove; $p \leq 0.05$; Zar 1999). In addition, the variance inflation factor (VIF) was used to estimate the level of collinearity among the explanatory variables in the multi-regression analysis. High or low VIF values represent high or low levels of collinearity, respectively, with the usual cut-off value of VIF $=10$. A VIF value close to 1 indicates that the variables are uncorrelated $(r \approx 0$; Hair et al. 1998). Analyses were performed using SPSS 17.0 (SPSS Inc., Chicago IL, USA).

Table 1

Descriptive statistics of questionnaire responses from mussel farmers $(n=49)$ representative of production capacity in Greece; survey period from November 2008 to February 2009

\begin{tabular}{|l|r|}
\hline Respondents (mussel farmers)/total Greek managing production capacity (t) & $31068 / 45403$ \\
\hline Production representation (\%) & 68 \\
\hline Questionnaire respondents (N/\%) & $49 * / 12$ \\
\hline Age of respondents (18-30 yr/31-40 yr/41-50 yr/51-60/61 yr <) (\%) & $9 / 19 / 40 / 21 / 11$ \\
\hline Work experience (yr) & $13.9 \pm 8.1$ \\
\hline Education (primary/secondary/higher) & $12 / 61 / 27$ \\
\hline Mussel farmers' managing capacity range (min.-max; $\mathrm{t}$ ) & $50-12000 *$ \\
\hline Mean farm production capacity per farm unit (including individual cooperative members of respondents; $\mathrm{t})$ & $225 \pm 152$ \\
\hline Mean farm size ownership per individual farmer, including cooperative members (ha) & $2.4 \pm 1.7$ \\
\hline Full-time occupation (workers/mussel farm) & $1.25 \pm 1.60$ \\
\hline Part-time occupation (workers/mussel farm) & $2.73 \pm 1.81$ \\
\hline Culture system (1 long line/2 hanging parks; \%) & $92 / 8$ \\
\hline Legal status of the mussel farm (1 self-employment/2 general partnership GP/limited partnership LP/3 Ltd/4 SA) (\%) & $44 / 36 / 5 / 15$ \\
\hline *including three cooperatives, with mean square values per 6, 40 and 53 members, respectively, representing a total production capacity of 1200 t, 7500 t and 12 000 t, respectively.
\end{tabular}


Table 2

Factor loadings (SERi) from factor analysis of socioeconomic variables on Greek mussel farmers and results of multivariate ANOVA (MANOVA; $p=0.05$ ) of factor scores per legal status and culture system. ExpVar\% - \% explained variance, CumExpVar\% - \% cumulative explained variance, with significant values marked in bold (cut-off value of $\pm 0.6)$, ns - non-significant statistical differences $(p>0.05)$

\begin{tabular}{|l|c|c|c|} 
& \multicolumn{3}{|c|}{ Factors } \\
\cline { 2 - 4 } & farm features & farm manager education & work experience \\
\hline Socioeconomic variables & SER1 & SER2 & SER3 \\
\hline Production capacity & $\mathbf{0 . 9 5}$ & 0.01 & -0.02 \\
\hline Farm size & $\mathbf{0 . 9 0}$ & -0.05 & 0.04 \\
\hline Part-time work & $\mathbf{0 . 8 1}$ & -0.15 & 0.05 \\
\hline Full-time work & $\mathbf{0 . 7 9}$ & 0.32 & -0.09 \\
\hline Age & -0.21 & $\mathbf{0 . 8 7}$ & 0.22 \\
\hline Education & -0.19 & -0.81 & 0.14 \\
\hline Work experience & 0.03 & 0.03 & $\mathbf{0 . 9 9}$ \\
\hline Eigenvalues & 3.07 & 1.55 & 1.06 \\
\hline ExpVar\% & 43.86 & 22.13 & 15.12 \\
\hline CumExpVar\% & 43.86 & 66.00 & 81.12 \\
\hline
\end{tabular}

\section{Results}

A total of 49 questionnaires were completed out of 424 distributed (12\%), three of which were completed by representatives of farmer unions/ cooperatives. The mean square values per 6, 40 and 53 members respectively were used in the last case. It was estimated that 49 respondents, representing 145 out of 425 farmers (34\%), managed $68 \%$ of the Greek mussel production farming capacity by volume on farms ranging from $50 \mathrm{t}$ (small farms) up to $12000 \mathrm{t}$ (large cooperatives) with a mean production capacity of $225 \pm 152 \mathrm{t}$ per farm (Table 1 ).

\subsection{Characteristics of Greek mussel farmers}

The largest proportion of respondents (40\%) were middle-aged farmers (41-50 yrs), followed by $21 \%$ of older farmers (51-60 yrs), 19\% aged 31-40 years, $11 \%$ approaching retirement age (> $61 \mathrm{yrs}$ ), and 9\% newcomers (18-30 yrs). The majority of respondents (61\%) were secondary school graduates, while $27 \%$ were university graduates, and the remaining $12 \%$ completed primary education. The number of part-time employees $(2.73 \pm 1.81)$ was higher than the number of full-time employees $(1.25 \pm 1.60)$ per mussel farm (Table 1).

\subsection{Typology of Greek mussel farms}

The predominant farm type operated by the respondents (Table 1) was the long line system (92\%), followed by hanging parks (8\%). Most of the farms (44\%) were operated under the legal status of sole proprietorship (self-employment), followed by $35 \%$ of general partnership (GP) and limited partnership (LP) in collaboration with other companies. Large entities such as limited partnership companies (5\%) and Société Anonyme/Anonymous Company - SA (15\%) had a small share.

\subsection{Socioeconomic farming features}

Table 2 shows that FA identified three factors with eigenvalues higher than 1 (> 1), explaining $81.12 \%$ of the total variance. Using a cut-off value of 0.60 for factor loadings, factor 1 explains $43.86 \%$ of the variance by socioeconomic variables related to farm features (farm size, production capacity and full- or part-time labor force) and factor 2 explains $22.13 \%$ of the variance related to farm-manager education (education and age), with an opposite (reverse) relationship between the age of a mussel farmer and his educational background. Young farmers had more opportunities to access the educational system compared to older farmers as the country 
Risk ranking by mean scores of questionnaire responses $(n=49)$; factor loadings for mussel farmers' willingness to take risks and results of multivariate ANOVA (MANOVA) of factor scores per legal status and culture system. ExpVar\% - \% explained variance, CumExpVar\% - \% cumulative explained variance, SD - standard deviation, with significant values marked in bold (cut-off value of \pm 0.6 ), ns - non-significant statistical differences $(p>0.1), \mathrm{S}, \mathrm{S}^{*}-$ significant statistical differences $p<0.05$ and $p<0.1$, respectively, the rank of mean values of homogeneous subsets given in parentheses (post hoc Tukey HSD test).

\begin{tabular}{|c|c|c|c|c|c|c|}
\hline \multirow{3}{*}{$\begin{array}{l}\text { Willing to take risk more than my colleagues } \\
\text { in production }\end{array}$} & \multirow{3}{*}{$\begin{array}{c}\text { Rank by Mean } \\
1\end{array}$} & \multicolumn{4}{|c|}{ Mean Scale \pm SD } & \multirow{3}{*}{$\begin{array}{c}\text { Factor loadings } \\
\text { Relative risk attitude (F1) } \\
0.91\end{array}$} \\
\hline & & \multicolumn{2}{|c|}{$(1-5)$} & \multicolumn{2}{|c|}{$1-100 \%$} & \\
\hline & & 3.16 & 1.33 & 63.27 & 26.57 & \\
\hline in marketing & 2 & 3.12 & 1.39 & 62.45 & 27.88 & 0.92 \\
\hline in farming in general & 3 & 3.02 & 1.20 & 60.41 & 23.98 & 0.98 \\
\hline more than other farmers* & 4 & 2.98 & 1.23 & 59.59 & 24.66 & 0.98 \\
\hline financial issues & 5 & 2.43 & 1.40 & 48.57 & 48.57 & 0.84 \\
\hline Farmer' risk attitude** & & 2.94 & 1.21 & 58.86 & 24.26 & \\
\hline Eigenvalues & \multicolumn{6}{|c|}{3.62} \\
\hline ExpVar\% & \multicolumn{6}{|c|}{72.35} \\
\hline CumExpVar\% & \multicolumn{6}{|c|}{72.35} \\
\hline \multicolumn{7}{|c|}{ MANOVA results } \\
\hline Legal status & \multicolumn{6}{|c|}{$S(4,3<2,3<1,3)$} \\
\hline Culture system & \multicolumn{6}{|c|}{ ns } \\
\hline
\end{tabular}

gradually modernized. Factor 3, explaining $15.12 \%$ of the variance, expresses the work experience of a farm manager and is related to his age and education.

All factors showed non-significant statistical differences between the legal status of enterprises and their culture systems (MANOVA; $p<0.1$ ).

\subsection{Perception of relative risk attitude}

"Relative risk attitude" of mussel farmers was measured to investigate their willingness to take risk. The FA factor loading explained $72.35 \%$ of the total initial risk variation (Table 3). Farmers were comfortable with risk-taking in production (fieldwork, $63.27 \pm 26.57 \%$ ) and marketing (daily contacts with wholesalers, $62.45 \pm 27.88 \%$ ), i.e. areas they are more familiar with than financial issues (use of financial products, $48.57 \pm 27.99 \%$ ). Greek mussel farmers tended not to take financial risks as they did consider themselves unfamiliar with the processes involved, for example, applying for a bank loan to finance modernization, or flexibility in dealing with wholesalers (they prefer to sell their products through local and well-known wholesale agents rather than other new and most promising traders). Their attitude toward risk is above average (58.86 $\pm 24.26 \%$ ), which coincides with their willingness to take more risk than others in the same business (59.59 $\pm 4.66 \%)$. Relative risk attitude showed significant statistical differences for the legal status of enterprises (MANOVA; $p<0.1$ ), with the gradation of mean relative risk attitude being SA < GP and LP < self-employment (post hoc Tukey HSD test; $p<0.05$ ). This may be a consequence of the fact that most mussel farmers are family businesses, which supports the observation that risk must be borne by individuals. Relative risk attitude showed statistically insignificant differences between farming systems (MANOVA; $p>0.1$; Table 3 ).

\subsection{Risk sources}

Responses of mussel farmers to Likert-type questions are presented as a percentage distribution (\%) of scores for different types of risk sources (Table 4). Table 4 shows the major identified sources of risk that affect mussel farming in descending order of importance. The five most important risk sources were ex-farm prices (mean value: $4.49 \pm 0.82$ ), operator's disability/health (4.20 \pm 1.17), vessel availability (4.18 \pm 1.47), HABs (4.12 \pm 1.11$)$, and farmer's family health $(4.02 \pm 1.13)$. Finally, scores from 27 to 33 represent risks with average values of less than $2.47 \pm 1.37$, estimated to have a low to moderate impact on mussel farming. These refer to pollution, environmental impact, sea rental (farm site leasing cost), illegal actions (i.e. cheating on mussel stock and equipment), environmental NGOs (protests against aquaculture activities, e.g. for conservation purposes), transport (delays in moving live/fresh mussel stock into the supply chain, which can cause losses, especially 
Table 4

Ranking of risk perception sources by mean scores (1 - not relevant, 5 - relevant); factor loadings from factor analysis (SRi) for risk sources and results of multivariate ANOVA (MANOVA) of factor scores per legal status and culture system. ExpVar\% - \% explained variance, CumExpVar\% - \% cumulative explained variance, SD - standard deviation, with significant values marked in bold (cut-off value of \pm 0.6 ). Mean scale evaluation (MSE): $M \geq 4-$ important (IM); $3 \leq M<4$ - high moderate (HM); $2 \leq \mathrm{M}<3$ - low moderate (LM); $\mathrm{Mi}<2$ - low (LO), ns - non-significant statistical differences $(p>0.1), \mathrm{S}, \mathrm{S}^{*}$ - significant statistical differences at $p<0.05$ and $p<0.1$, respectively, the rank of mean values of homogeneous subsets given in parentheses (post hoc Tukey HSD test)

\begin{tabular}{|c|c|c|c|c|c|c|c|c|c|c|c|c|c|c|c|}
\hline \multirow{2}{*}{ ID } & \multirow{2}{*}{ Risk Sources (RS) variables } & \multirow{2}{*}{$\begin{array}{c}\text { Rank by } \\
\text { Mean }\end{array}$} & \multirow{2}{*}{$\begin{array}{c}\text { Mean } \\
\text { (M) }\end{array}$} & \multirow{2}{*}{ SD } & \multirow{2}{*}{ MSE } & \multicolumn{10}{|c|}{ Factors } \\
\hline & & & & & & SR1 & SR2 & SR3 & SR4 & SR5 & SR6 & SR7 & SR8 & SR9 & SR10 \\
\hline 8 & Availability of grading machines & 9 & 3.65 & 1.38 & $\mathrm{HM}$ & -0.83 & -0.23 & 0.06 & -0.19 & -0.13 & 0.05 & -0.16 & 0.14 & -0.07 & 0.01 \\
\hline 20 & Health \& safety & 26 & 2.73 & 1.44 & LM & 0.73 & -0.34 & -0.02 & -0.06 & -0.11 & 0.26 & 0.13 & 0.18 & 0.23 & 0.03 \\
\hline 6 & Technology availability & 14 & 3.41 & 1.21 & $\mathrm{HM}$ & -0.72 & -0.15 & 0.10 & -0.15 & 0.05 & -0.01 & -0.12 & -0.06 & 0.43 & 0.08 \\
\hline 7 & Vessel availability & 3 & 4.18 & 1.47 & IM & -0.58 & -0.29 & 0.32 & -0.13 & -0.19 & 0.02 & -0.25 & 0.35 & 0.10 & 0.06 \\
\hline 33 & Division of tasks within family & 20 & 3.22 & 1.43 & $\mathrm{HM}$ & 0.57 & 0.41 & 0.46 & 0.19 & 0.05 & 0.19 & -0.15 & -0.14 & 0.10 & 0.03 \\
\hline 32 & Family relations & 12 & 3.49 & 1.32 & $\mathrm{HM}$ & 0.48 & 0.46 & 0.42 & 0.11 & 0.26 & 0.27 & -0.22 & -0.11 & 0.06 & 0.19 \\
\hline 31 & Disability/health of farmer & 2 & 4.20 & 1.17 & IM & 0.13 & 0.91 & 0.06 & -0.06 & 0.07 & 0.19 & -0.05 & 0.00 & -0.03 & 0.12 \\
\hline 30 & Health situation of farmer family & 5 & 4.02 & 1.13 & IM & 0.09 & 0.90 & 0.13 & 0.01 & 0.03 & 0.16 & 0.05 & -0.03 & -0.06 & 0.04 \\
\hline 28 & Possibility to remit loans & 17 & 3.33 & 1.49 & $\mathrm{HM}$ & -0.11 & 0.02 & 0.88 & -0.16 & -0.03 & 0.03 & 0.07 & 0.12 & -0.04 & -0.02 \\
\hline 27 & Changes in interest rates & 11 & 3.49 & 1.43 & $\mathrm{HM}$ & 0.00 & 0.16 & 0.85 & -0.11 & 0.01 & 0.01 & 0.11 & 0.15 & -0.04 & 0.09 \\
\hline 23 & Public Authorities Services & 10 & 3.65 & 1.45 & $\mathrm{HM}$ & -0.07 & -0.33 & 0.46 & 0.40 & -0.07 & -0.11 & 0.31 & 0.03 & 0.16 & -0.12 \\
\hline 16 & Freshwater availability & 15 & 3.41 & 1.17 & $\mathrm{HM}$ & 0.15 & 0.10 & 0.01 & 0.80 & -0.20 & -0.14 & 0.21 & -0.02 & 0.08 & 0.20 \\
\hline 19 & Environmental impact & 28 & 2.37 & 1.41 & LM & 0.13 & -0.25 & -0.25 & 0.79 & 0.10 & 0.31 & 0.03 & -0.07 & -0.08 & -0.05 \\
\hline 17 & Diseases & 33 & 1.76 & 1.20 & LO & 0.35 & 0.20 & -0.07 & 0.63 & 0.39 & -0.07 & 0.06 & -0.19 & 0.29 & -0.23 \\
\hline 1 & Weather impact & 22 & 3.08 & 1.22 & $\mathrm{HM}$ & 0.27 & 0.52 & -0.28 & 0.53 & -0.17 & 0.14 & 0.17 & 0.10 & -0.03 & -0.19 \\
\hline 2 & Seed recruitment availability & 13 & 3.41 & 1.15 & $\mathrm{HM}$ & -0.10 & 0.03 & 0.04 & 0.03 & -0.87 & -0.05 & 0.07 & 0.05 & 0.09 & 0.01 \\
\hline 10 & Ex-farm mussel price & 1 & 4.49 & 0.82 & IM & 0.06 & 0.21 & -0.05 & 0.14 & 0.65 & 0.12 & 0.23 & 0.41 & 0.14 & 0.09 \\
\hline 29 & Sea rental & 29 & 2.18 & 1.27 & LM & -0.22 & 0.21 & 0.10 & -0.26 & 0.47 & 0.39 & 0.09 & 0.22 & -0.36 & -0.01 \\
\hline 3 & Mussel meat yield & 16 & 3.33 & 1.20 & $\mathrm{HM}$ & 0.29 & 0.25 & -0.34 & 0.27 & -0.47 & 0.04 & -0.13 & -0.07 & -0.05 & 0.41 \\
\hline 22 & $\mathrm{NGOS}$ & 31 & 1.90 & 1.08 & LO & -0.04 & 0.13 & 0.16 & -0.05 & 0.06 & 0.82 & -0.03 & 0.13 & 0.04 & 0.25 \\
\hline 21 & Media & 21 & 3.20 & 1.62 & $\mathrm{HM}$ & 0.13 & 0.35 & -0.15 & 0.19 & 0.26 & 0.68 & 0.10 & -0.06 & -0.22 & -0.07 \\
\hline 18 & Illegal actions & 30 & 2.02 & 1.25 & LM & 0.36 & 0.30 & -0.12 & 0.13 & -0.02 & 0.63 & 0.05 & -0.05 & 0.15 & -0.26 \\
\hline 26 & New license availability & 19 & 3.22 & 1.37 & $\mathrm{HM}$ & 0.27 & 0.14 & 0.39 & 0.07 & 0.11 & -0.04 & 0.73 & -0.08 & 0.11 & 0.08 \\
\hline 25 & Environmental Policy & 8 & 3.86 & 1.32 & $\mathrm{HM}$ & 0.07 & -0.12 & -0.04 & 0.30 & -0.03 & -0.11 & 0.66 & -0.08 & 0.18 & -0.13 \\
\hline 12 & Transport & 32 & 1.86 & 1.12 & LO & -0.03 & -0.21 & 0.28 & -0.11 & -0.19 & 0.43 & 0.63 & -0.11 & -0.22 & 0.08 \\
\hline 11 & Supply absorption & 6 & 3.94 & 1.03 & $\mathrm{HM}$ & 0.16 & 0.23 & -0.12 & 0.07 & 0.40 & 0.29 & 0.61 & 0.17 & -0.07 & 0.08 \\
\hline 5 & Production cost & 7 & 3.92 & 0.73 & $\mathrm{HM}$ & 0.01 & 0.06 & 0.06 & -0.01 & 0.29 & 0.13 & -0.13 & 0.75 & -0.08 & 0.11 \\
\hline 9 & Labor availability & 18 & 3.29 & 1.43 & HM & -0.33 & -0.13 & 0.40 & -0.08 & -0.07 & -0.05 & 0.03 & 0.71 & 0.04 & -0.17 \\
\hline 14 & Pollution & 27 & 2.47 & 1.37 & LM & -0.27 & 0.24 & -0.02 & 0.46 & 0.23 & 0.21 & 0.02 & -0.50 & 0.21 & 0.02 \\
\hline 24 & Termination of governmental support & 25 & 2.86 & 1.40 & LM & -0.07 & 0.03 & 0.22 & 0.08 & -0.11 & 0.04 & -0.04 & -0.07 & 0.81 & 0.13 \\
\hline 13 & Harmful algal blooms (HABS) & 4 & 4.12 & 1.11 & IM & 0.08 & -0.10 & -0.29 & 0.06 & 0.06 & -0.07 & 0.20 & 0.01 & 0.76 & -0.04 \\
\hline 4 & Fouling organisms & 23 & 2.98 & 1.03 & LM & -0.02 & 0.04 & 0.00 & 0.04 & 0.06 & 0.06 & 0.02 & -0.02 & 0.14 & 0.95 \\
\hline 15 & Predators & 24 & 2.86 & 1.65 & LM & -0.13 & 0.24 & 0.33 & -0.29 & -0.20 & -0.01 & 0.03 & 0.39 & -0.15 & 0.61 \\
\hline \multicolumn{6}{|c|}{ Eigenvalues } & 3.51 & 3.49 & 3.23 & 2.91 & 2.49 & 2.46 & 2.28 & 2.07 & 2.05 & 1.89 \\
\hline \multicolumn{6}{|c|}{ ExpVar\% } & 10.65 & 10.57 & 9.79 & 8.81 & 7.55 & 7.47 & 6.91 & 6.27 & 6.21 & 5.73 \\
\hline \multicolumn{6}{|c|}{ CumExpVar\% } & 10.65 & 21.21 & 31.01 & 39.81 & 47.37 & 54.83 & 61.74 & 68.01 & 74.22 & 79.95 \\
\hline
\end{tabular}

Legal status

Culture system

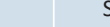

ns \begin{tabular}{l|l|l|l|l}
$S$ & $S$ &
\end{tabular}

$(4<$ ns $\quad$ ns $\quad$ ns $(1,2,4<(1,2,3$

$1,2,3)$

ns

$3,4,2) \quad 2,3,4)$

$\mathrm{S} \quad \mathrm{ns}$

ns ns $\mathrm{S}^{*}$

Factors 1 to 10 are best described as: health safety OR technology availability, personal welfare, financial risk, environmental risk, market risk, social acceptance, institutional, production cost \& labor availability, $\mathrm{HABs}$, biofouling \& predators. 
on long-distance export markets in summer), and diseases.

Using factor analysis (FA), the original 33 sources of risk (SR) were reduced to 10 (SR) explaining $79.95 \%$ of the total initial variance (Table 4). SR1 explaining $10.65 \%$ of the variance described as "health safety OR technology availability" is associated with mussel farmer's perception of the effect of health safety policies (positive association) and availability of grading machines and technology (negative association).

SR2, explaining $10.57 \%$ of the variance, is described as "personal welfare" and is associated with mussel farmer's perception of the effect of health status of the farmer and his family (risks: disability and loss of health of a farm operator and the health situation of farmer's family).

SR3 explains $9.79 \%$ of the variance and is described as "financial risk" associated with mussel farmer's perception of the effect on the farm of the farmer's ability to manage interest rate changes and loan repayments.

SR4 explains $8.81 \%$ of the variance and is described as "environmental risk" associated with mussel farmer's perception of the effect of freshwater availability mainly through rainfall (resulting in high salinity and nutrient losses that indicate limitations on algal food availability in estuarine ecosystems where most of the mussel farms are located), diseases and general environmental impact.

SR5 explains $7.55 \%$ of the variance and is described as "market risk" associated with mussel farmer's perception of the effect of ex-farm prices, and negatively associated with seed recruitment.

SR6 explains $7.47 \%$ of the variance and is described as "social acceptance" associated with mussel farmer's perception of the effect of public opinion, usually influenced or induced by NGOs and the media highlighting malpractice by farms.

SR7 explains $6.91 \%$ of the variance and is described as "institutional" associated with mussel farmer's perception of the effect on the farm of policies related to transportation (new legal standards for the supply chain), absorption of supplies, environmental regulations and availability of new licenses.

SR8 explains $6.27 \%$ of the variance and is described as "production cost \& labor availability" associated with mussel farmer's perception of the effect of production cost \& labor availability.

SR9 explains $6.21 \%$ of the variance and is described as "HABs" associated with mussel farmer's perception of the effect of harmful algal blooms and government actions (bans etc.) on the farm.

SR10 explains $5.73 \%$ of the variance and is described as "biofouling \& predators" associated with mussel farmer's perception of the effect of biofouling and predator attacks.

Health safety $O R$ technology availability, financial risk, environmental risk, market risk, production cost \& labor availability, and $H A B s$ showed statistically insignificant differences between the two mussel culture systems (MANOVA; $p>0.1$ ). Mean score values of personal welfare, social acceptance, and institutional showed statistically significant differences for the legal status of enterprises (anonymous companies $<$ other types of legal status; self-employment < general partnership GP and limited partnership LP; self-employment < anonymous companies, respectively; MANOVA; post hoc Tukey HSD test; $p<0.05$ ). This may be due to the fact that most farmers are self-employed.

The mean values of social acceptance and biofouling \& predators scores showed statistically significant differences between the two culture systems (long line < hanging parks; hanging parks < long line, respectively; MANOVA; post hoc Tukey HSD test; $p<0.1)$. Hanging parks are located within Natura 2000 protected zones, but they also have a strong social influence on local communities (mussel farming is a labor-intensive activity that provides employment, so farmers have significant political influence on local and national elections). Biofouling can be more easily managed in hanging parks compared to long lines (e.g. exposure of mussels to air to kill ascidians, etc.).

\subsection{Risk Management Strategies}

Table 5 shows the mean scores for the risk management strategies of Greek mussel farmers. The preferred strategy was the provision of financial and credit reserves $(4.84 \pm 0.43)$. Strategies with "low impact" (scores below 3) are ranked between 13 and 15. They include sale price contracts, personal insurance policies, and species diversification. All three are absent or of minimal relevance. Strategies that scored between high and low values (ranked from 2 to 12) have "moderate impact" with mean values considerably below the first option $(3.65 \pm 1.65$ to 
Table 5

Ranking of risk management strategies by mean scores ( 1 - not relevant, 5 - relevant). Factor loadings (RSMi) for risk sources and results of multivariate ANOVA (MANOVA) of factor scores per legal status and culture system. ExpVar\% - \% explained variance, CumExpVar\% - \% cumulative explained variance, SD - standard deviation, with significant values marked in bold (cut-off value of \pm 0.6 ). Mean scale evaluation (MSE): $M \geq 4-$ important (IM); $3 \leq M<4-$ high moderate (HM); $2 \leq \mathrm{M}<3$ - low moderate (LM); Mi $<2$ - low (LO), ns - non-significant statistical differences $(p>0.1)$, $\mathrm{S}, \mathrm{S}^{*}$ - significant statistical differences $p<0.05$ and $p<0.1$, respectively, the rank of mean values for homogeneous subsets given in parentheses (post hoc Tukey HSD test).

\begin{tabular}{|c|c|c|c|c|c|c|c|c|c|c|}
\hline \multirow{2}{*}{ ID } & \multirow{2}{*}{ Risk Management Strategies (RMS) } & \multirow{2}{*}{$\begin{array}{c}\text { Rank by } \\
\text { Mean }\end{array}$} & \multirow{2}{*}{ Mean } & \multirow{2}{*}{ SD } & \multirow{2}{*}{ MSE } & \multicolumn{5}{|c|}{ Risk Management Strategies Factors } \\
\hline & & & & & & RMS1 & RMS2 & RMS3 & RMS4 & RMS5 \\
\hline 8 & Off-farm employment (agri-farming, commerce, services) & 2 & 3.65 & 1.65 & $\mathrm{HM}$ & 0.85 & 0.17 & -0.21 & -0.12 & -0.10 \\
\hline 7 & Off-farm investment (i.e. agritourism, stock market) & 8 & 3.37 & 1.39 & $\mathrm{HM}$ & 0.75 & 0.17 & 0.22 & 0.12 & -0.09 \\
\hline 2 & Strict adherence to hygienic and environmental rules & 9 & 3.24 & 1.15 & $\mathrm{HM}$ & -0.66 & 0.17 & -0.04 & 0.01 & -0.01 \\
\hline 4 & Financial and credit reserves & 1 & 4.84 & 0.43 & IM & 0.51 & -0.16 & -0.22 & 0.31 & 0.46 \\
\hline 14 & Price contracts for sales & 13 & 2.65 & 1.55 & LM & 0.03 & 0.80 & -0.08 & 0.19 & -0.08 \\
\hline 5 & Spatial diversification (other species) & 15 & 2.08 & 1.29 & LM & 0.10 & 0.76 & 0.08 & -0.08 & -0.03 \\
\hline 6 & Participation in government supporting programs & 7 & 3.45 & 1.44 & $\mathrm{HM}$ & -0.08 & 0.66 & 0.03 & 0.00 & 0.20 \\
\hline 11 & Buying boat insurance & 10 & 3.24 & 1.48 & $\mathrm{HM}$ & 0.06 & -0.20 & 0.81 & 0.28 & -0.06 \\
\hline 12 & Buying business insurance & 11 & 3.10 & 1.45 & HM & 0.13 & 0.11 & 0.75 & -0.51 & -0.05 \\
\hline 13 & Buying personal insurance & 14 & 2.22 & 1.37 & LM & -0.18 & 0.38 & 0.67 & 0.14 & 0.36 \\
\hline 15 & Collaboration in trade (vertical) & 5 & 3.47 & 1.53 & HM & 0.33 & 0.05 & 0.07 & 0.74 & 0.10 \\
\hline 3 & Collaboration in production (horizontal) & 4 & 3.53 & 1.40 & $\mathrm{HM}$ & -0.01 & 0.03 & 0.33 & 0.63 & 0.39 \\
\hline 10 & Business diversification & 6 & 3.45 & 1.58 & $\mathrm{HM}$ & -0.02 & -0.36 & 0.18 & 0.03 & -0.72 \\
\hline 9 & Geographic dispersion & 12 & 3.06 & 1.77 & $\mathrm{HM}$ & -0.10 & -0.09 & 0.21 & 0.06 & 0.69 \\
\hline \multicolumn{6}{|c|}{ Eigenvalues } & 2.32 & 2.12 & 2.04 & 1.95 & 1.62 \\
\hline \multicolumn{6}{|c|}{ ExpVar\% } & 15.46 & 14.12 & 13.58 & 12.98 & 10.82 \\
\hline \multicolumn{6}{|c|}{ CumExpVar\% } & 15.46 & 29.58 & 43.16 & 56.14 & 66.96 \\
\hline \multicolumn{11}{|c|}{ MANOVA results } \\
\hline \multicolumn{6}{|c|}{ Legal status } & ns & ns & $\begin{array}{c}S \\
(1,2,4<3)\end{array}$ & ns & ns \\
\hline \multicolumn{6}{|c|}{ Culture system } & ns & ns & $S^{*}(1<2)$ & ns & ns \\
\hline
\end{tabular}

Factors 1 to 5 are best described as: Off-farm employment OR Applying strict hygienic rules, Intra-company measures, Insurance, Integration OR Production at lowest cost, Geographic dispersion OR Business diversification.

$3.06 \pm 1.77)$. Except for "financial and credit reserves", all other variables from 2 to 11 are within $85 \%$ of importance in the ranking of farmers. These are not ways to intensify their core business, but to seek alternative ways to make a living. It can be concluded that mussel farming business is unstable. Moderate impact strategies include employment of farmers in other businesses (e.g. agribusiness, commerce), cost reduction and collaboration between farmers either horizontally (by sharing equipment, supplies, labor, etc.) or vertically in trade and commerce. Other moderate impact strategies include business diversification (in processing, fishing, distribution), participation in public support programs, off-farm investments (e.g. agritourism, stock market), boat insurance policy, adherence to strict hygiene rules, business insurance policy, and spatial diversification (geographic dispersion of the business).
Similar to the sources of risk, the 15 identified risk management strategy (RMS) variables were reduced by FA to five factors (RMS), explaining $66.96 \%$ of the total initial variance (Table 5).

Mussel farmers seek "off-farm employment OR apply strict hygienic rules" (RMS1, explaining 15.46\% of the total variance) through off-farm investment and employment, and alternatively on-farm adherence to strict hygiene and environmental rules.

In addition, farmers use "intra-company measures" through negotiation of price contracts for sales, spatial diversification into other species and participation in government supporting programs (RMS2 explaining $14.12 \%$ of the variance).

RMS3, explaining $13.58 \%$ of the variance and described as "insurance", refers to farmers' willingness to purchase personal, business and boat insurance.

RMS4, explaining $12.98 \%$ of the variance and 
described as "integration", refers to horizontal and vertical integration between farmers (production and trade) and alternatively to production at the lowest possible cost.

Finally, RMS5, explaining $10.82 \%$ of the variance and described as "geographic dispersion OR business diversification", refers to strategies of geographically dispersing the business or grouping it together (business diversification) with other activities such as fishing, processing and distribution networks.

Only the mean of Insurance scores showed statistically significant differences for the legal status (self-employment < general partnership GP and limited partnership LP) and culture systems (long line $<$ hanging parks; MANOVA; post hoc Tukey HSD test; $p<0.1$.

Responses to the open-ended questions (Table 6) show that all mussel farmers (100\%) were familiar with risk management associated with daily farming activities during their routine operations. They expressed interest in purchasing insurance tailored for their boats (44.9\%) and protection from weather impacts (14.3\%). Farmers also want public funds to be used to compensate for losses caused by extended harvest bans due to harmful algal blooms (79.6\%), predation attacks $(51.0 \%)$, pollution $(26.5 \%)$, diseases (8.2\%) and illegal actions (8.2\%).

The path analysis framework (Fig. 1) demonstrates the relative links (B) between the risk management strategies, the risk factors and the socioeconomic status of Greek mussel farmers.

Figure 2 shows the significant relationships through the paths. The explained variance of RMS variables by the SER and SR variables ranged from $21 \%\left(R^{2}=0.21\right)$ for "Geographic dispersion OR Business diversification" to $56 \%\left(R^{2}=0.56\right)$ for "Intra-company measures". On the other hand, the explained variance of the SR variables by the SER variables ranged from $0 \%\left(\mathrm{R}^{2}=0\right)$ for "Institutional" and "Biofouling \& predators" to $26 \%\left(R^{2}=0.26\right)$ for "Health safety $O R$ Technology availability". The VIF ranged from 1 to 1.53 and indicated that the independent variables were uncorrelated.

The total, non-causal, direct and indirect effects and the association effect ( $r=$ correlation coefficient, estimated by MGR as zero order coefficient) of each independent variable with each dependent variable (Table 7) were estimated using the B values shown in Figure 2.

The total association of risk management strategy factors (RMS) "Off-farm employment OR Applying strict hygienic rules" is statistically significant with risk factors (SRs) "Health safety OR Technology availability" (0.272), "Environmental risk" (-0.511) and with "Production cost \& Labor availability" (0.287). The direct and indirect effects of "Health safety OR Technology availability" were 0.272 and 0.138 through socioeconomic factors SER "Relative risk attitude" and the percentage of the total absolute effect (PTAE) $66.22 \%$ and $33.77 \%$, respectively, of "Environmental risk" were -0.51 (PTAE $=71.42 \%$ ) and -0.20 (PTAE $=28.57 \%)$ through SER "Work experience" and of "Production cost \& Labor availability" 0.287 (PTAE = $77.51 \%)$ and $-0.08($ PTAE $=22.48 \%)$ through SER "Work experience".

Total association of RMS "Intra-company measures" is statistically significant with SRs "Health safety OR Technology availability" (-0.414),"Environmental risk" $(-0.338)$ and with "Social acceptance" $(-0.240)$ and "Institutional" (-0.286), as well as with SERs "Relative risk attitude" (-0.355) and "Farm features" (-0.195). The direct and indirect effects of "Relative risk attitude" were -0.34 (PTAE $=100 \%$ ) and 0 , respectively, of "Health safety OR Technology availability" -0.26 $($ PTAE $=66.22 \%)$ and $-0.13($ PTAE $=33.77 \%)$ through SER "Relative risk attitude", of "Environmental risk"

Table 6

Results of open-ended questions (\% of respondents' responses)

\begin{tabular}{|l|c|c|c|}
\hline \multicolumn{1}{|c|}{ Risk sources variables } & $\begin{array}{c}\text { What risks do } \\
\text { you } \\
\text { consider } \\
\text { manageable? }\end{array}$ & $\begin{array}{c}\text { For what types of risks would you like to } \\
\text { purchase insurance? }\end{array}$ & $\begin{array}{c}\text { What type of risk could be covered by public/ } \\
\text { government support? }\end{array}$ \\
\hline Weather impact & 0 & 14.3 & 51.0 \\
\hline Harmful algal blooms & 0 & 0.0 & 79.6 \\
\hline Pollution & 0 & 2.0 & 26.5 \\
\hline Predators & 0 & 0.0 & 57.1 \\
\hline Diseases & 0 & 0.0 & 8.2 \\
\hline Illegal actions & 0 & 0.0 & 8.2 \\
\hline Uninsured boat & 100 & 44.9 & 0.0 \\
\hline Farming in general \\
(routine production handling)
\end{tabular}




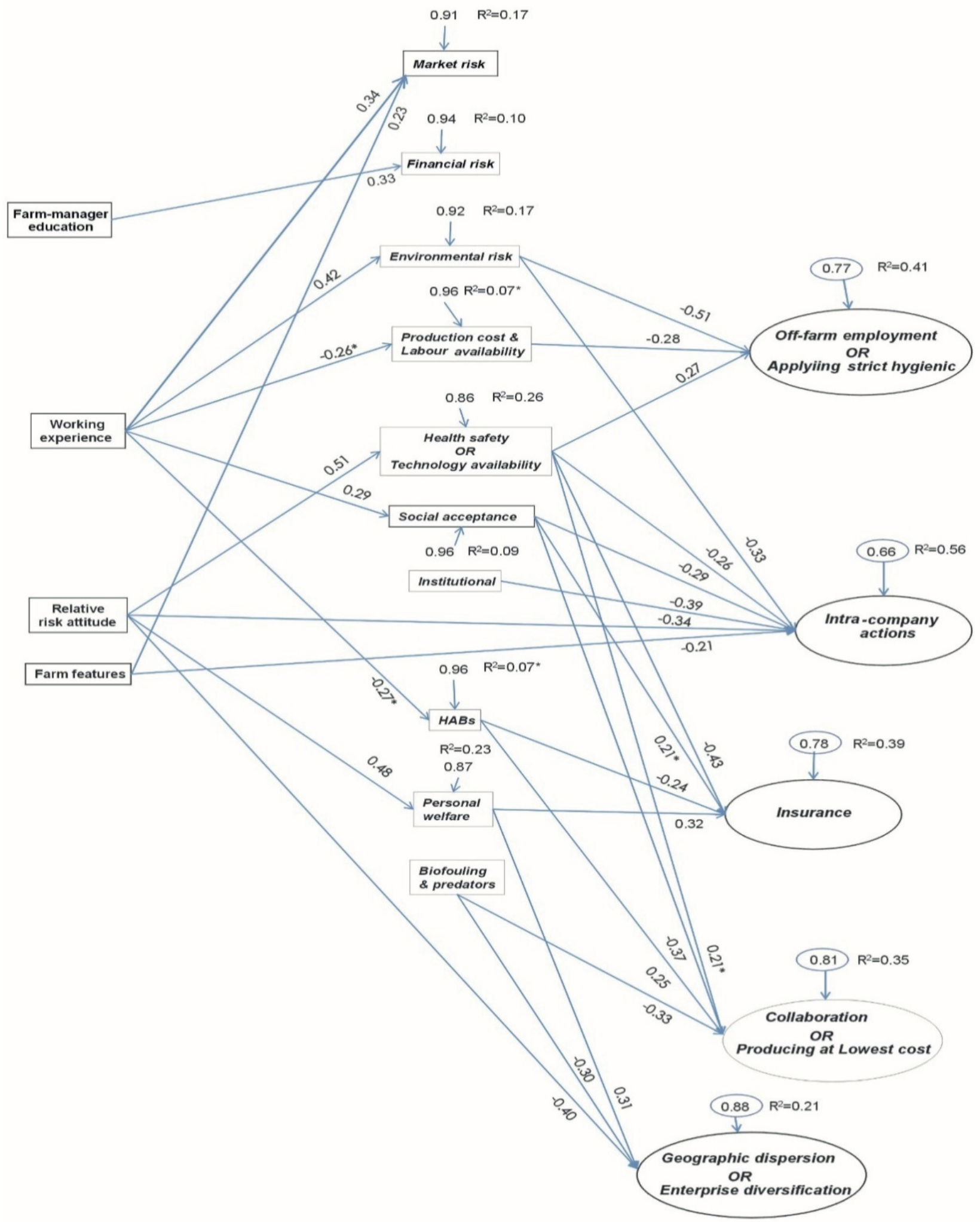

\section{Figure 2}

Path diagram (statistically significant flows; $p<0.05$ and ${ }^{*}-p<0.1$ ) for risk management strategies in relation to socioeconomic and risk factors of Greek mussel farmers. Values on the arrows are standardized regression coefficients. 
Effects of the relative risk attitude factor, socioeconomic factors (SER) and sources of risk factors (SR) on risk management strategy factors (RMS) determined by path analysis for Greek mussel farmers. Percentages of the absolute effect of independent variables on RMS given in parentheses.

\begin{tabular}{|c|c|c|c|c|c|c|c|}
\hline \multirow{2}{*}{ RMS } & \multirow[b]{2}{*}{ SER and SR } & \multirow[b]{2}{*}{ Direct effect } & \multicolumn{2}{|c|}{ Indirect effect through } & \multirow[b]{2}{*}{$\begin{array}{l}\text { Total } \\
\text { effect }\end{array}$} & \multirow[b]{2}{*}{$\begin{array}{c}\text { Total } \\
\text { association }\end{array}$} & \multirow[b]{2}{*}{$\begin{array}{c}\text { Non-causal } \\
\text { Effect }\end{array}$} \\
\hline & & & $\begin{array}{l}\text { Relative risk } \\
\text { attitude }\end{array}$ & $\begin{array}{c}\text { Work } \\
\text { experience }\end{array}$ & & & \\
\hline \multirow{3}{*}{$\begin{array}{l}\text { Off-farm employment or } \\
\text { Applying strict hygienic rules }\end{array}$} & $\begin{array}{l}\text { Health safety OR Technology } \\
\text { availability }\end{array}$ & $0.272(66.22 \%)$ & $0.138(33.77 \%)$ & & 0.411 & 0.272 & -0.14 \\
\hline & Environmental risk & $-0.51(71.42 \%)$ & & $-0.20(28.57 \%)$ & -0.715 & -0.511 & 0.20 \\
\hline & $\begin{array}{l}\text { Production cost \& Labor } \\
\text { availability }\end{array}$ & $0.287(77.51 \%)$ & & $-0.08(22.48 \%)$ & 0.204 & 0.287 & 0.08 \\
\hline \multirow{6}{*}{ Intra-company measures } & Relative risk attitude & $-0.34(100 \%)$ & & & -0.341 & -0.355 & -0.01 \\
\hline & $\begin{array}{l}\text { Health safety OR Technology } \\
\text { availability }\end{array}$ & $-0.26(66.22 \%)$ & $-0.13(33.77 \%)$ & & -0.396 & -0.414 & -0.02 \\
\hline & Environmental risk & $-0.33(71.42 \%)$ & & $-0.13(28.57 \%)$ & -0.471 & -0.338 & 0.13 \\
\hline & Social acceptance & $-0.28(77.51 \%)$ & & $-0.08(22.48 \%)$ & -0.373 & -0.240 & 0.13 \\
\hline & Institutional & $-0.39(100 \%)$ & & & -0.392 & -0.286 & 0.11 \\
\hline & Farm features & $-0.21(100 \%)$ & & & -0.215 & -0.195 & 0.02 \\
\hline \multirow{4}{*}{ Insurance } & $\begin{array}{l}\text { Health safety OR Technology } \\
\text { availability }\end{array}$ & $-0.43(66.22 \%)$ & $-0.21(33.77 \%)$ & & -0.651 & -0.431 & 0.22 \\
\hline & Personal welfare & $0.320(63.29 \%)$ & $0.186(36.70 \%)$ & & 0.507 & 0.321 & -0.19 \\
\hline & Social acceptance & $0.216(100 \%)$ & & & 0.217 & 0.217 & 0.00 \\
\hline & HABs & $-0.24(78.74 \%)$ & & $0.065(21.25 \%)$ & -0.177 & -0.242 & -0.07 \\
\hline \multirow{4}{*}{$\begin{array}{c}\text { Collaboration OR Production } \\
\text { at lowest cost }\end{array}$} & $\begin{array}{l}\text { Health safety OR Technology } \\
\text { availability }\end{array}$ & $0.218(66.22 \%)$ & $0.111(33.77 \%)$ & & 0.330 & 0.219 & -0.11 \\
\hline & Biofouling \& predators & $-0.32(100 \%)$ & & & -0.329 & -0.329 & 0.00 \\
\hline & Social acceptance & $-0.37(77.51 \%)$ & & $-0.10(22.48 \%)$ & -0.480 & -0.372 & 0.11 \\
\hline & HABs & $0.240(78.74 \%)$ & & $-0.06(21.25 \%)$ & 0.175 & 0.240 & 0.06 \\
\hline \multirow{3}{*}{$\begin{array}{l}\text { Geographic dispersion OR } \\
\text { Business diversification }\end{array}$} & Relative risk attitude & $-0.40(100 \%)$ & & & -0.401 & -0.224 & 0.18 \\
\hline & Biofouling \& predators & $-0.30(100 \%)$ & & & -0.307 & -0.271 & 0.04 \\
\hline & Personal welfare & $0.312(67.56 \%)$ & $0.150(32.43 \%)$ & & 0.494 & 0.120 & -0.37 \\
\hline
\end{tabular}

-0.33 (PTAE = 71.42\%) and $-0.13(\mathrm{PTAE}=28.57 \%)$ through SER "Work experience", of "Social acceptance" -0.28 (PTAE $=77.51 \%$ ) and -0.08 (PTAE $=22.48 \%$ ) through SER "Work experience", while the direct effects of "Institutional" and "Farm features" were -0.39 (PTAE = 100\%) and -0.21 (PTAE = 100\%), respectively.

The total association of RMS "Insurance" is statistically significant with SRs "Health safety OR Technology availability" (-0.43), "Personal welfare" (0.32) and with "Social acceptance" (0.216) and "HABs" $(-0.24)$. The direct and indirect effects of "Health safety OR Technology availability" were -0.43 (PTAE $=66.22 \%)$ and -0.21 (PTAE $=33.77 \%)$ through SER "Relative risk attitude", of "Personal welfare" 0.320 (PTAE $=63.29 \%)$ and $0.186(\mathrm{PTAE}=36.70 \%)$ through SER "Relative risk attitude", of "HABs" -0.24 (PTAE $=78.74 \%)$ and 0.065 (PTAE $=21.25 \%)$ through SER "Work experience", while the direct effects of "Social acceptance" were 0.216 (PTAE = 100\%).
The total association of RMS "Collaboration OR Production at lowest cost" is statistically significant with SRs "Health safety OR Technology availability" (0.219), "Biofouling \& predators" (-0.329) and with "Social acceptance" (-0.372) and "HABs" (0.240). The direct and indirect effects of "Health safety OR Technology availability" were 04218 (PTAE = 66.22\%) and 0.111 (PTAE = 33.77\%) through SER "Relative risk attitude", of "Social acceptance" -0.37 (PTAE = 77.51\%) and -0.10 (PTAE = 22.48\%) through SER "Work experience", of "HABs" -0.24 (PTAE = 78.74\%) and 0.06 (PTAE $=21.25 \%)$ through SER "Work experience", while the direct effects of "Biofouling \& predators" were -0.32 (PTAE = 100\%).

The total association of RMS "Geographic dispersion OR Business diversification" was statistically significant with SRs "Biofouling \& predators" (-0.271), "Personal welfare" (0.120), as well as with SERs "Relative risk attitude" (-0.224). The direct and indirect effects of "Personal welfare" were 0.312 (PTAE = 67.56\%) 
and 0.150 (PTAE $=32.43 \%$ ) through SER "Relative risk attitude", while the direct effects of "Biofouling \& predators" and "Relative risk Attitude" were -0.30 $(\mathrm{PTAE}=100 \%)$ and $-0.40(\mathrm{PTAE}=100 \%)$, respectively. Furthermore, Table 8 shows the results of the path analysis and the total absolute effects of the relative risk attitude factor, the socioeconomic factors (SER) and sources of risks factors (SR) on risk management strategy factors (RMS) for Greek mussel farmers. For "Off-farm employment" or "Applying strict hygienic rules," the dominant absolute effect was given by the "Environmental risk" (0.510); for "Intra-company measures" - by "Relative risk attitude" (0.475) and "Institutional" (0.391); for "Insurance" - by "Relative risk attitude" (0.405) and "Health safety OR Technology availability" (0.431); for "Collaboration OR Production at lowest cost" - by "Social acceptance" (0.391) and "Biofouling \& predators" (0.328); and for "Geographic dispersion OR Business diversification" - by "Relative risk attitude" (0.551).

\section{Discussion}

\subsection{Perception of risks}

Most respondents agreed that fluctuations in ex-farm prices are the main source of risk. This is critical for the viability of most farms, because while production costs have increased considerably (oil price, taxes, and wages), ex-farm prices of mussels have remained rather stable for over a decade (Theodorou et al. 2011; Theodorou et al. 2014). Ex-farm prices may constitute a major source of risk in exported seafood (e.g. Danish mussels: Nguyen 2012a,b; Thong 2012; Vietnamese catfish: Le \& Cheong 2010; Norway salmon: Bergfjord 2009), in contrast to products that support well-established local demands (e.g. oysters in France: Le Bihan et al. 2013). This situation explains the sensitivity of the Greek industry to ex-farm prices, as the major part of the mussel production is for export (Theodorou et al. 2011). Mussel farming is a

Table 8

Total absolute effects of the relative risk attitude factor, socioeconomic factors (SER) and sources of risks factors (SR) on risk management strategy factors (RMS) determined for Greek mussel farmers by path analysis

\begin{tabular}{|c|c|c|c|c|c|c|}
\hline \multirow{2}{*}{\multicolumn{2}{|c|}{$\begin{array}{l}\text { Relative risk attitude factor, } \\
\text { Socioeconomic factors (SER) and } \\
\text { Sources of risk factors (SR) }\end{array}$}} & \multicolumn{5}{|c|}{ Risk Management Strategy factors (RMS) } \\
\hline & & $\begin{array}{l}\text { Off-farm employment OR } \\
\text { Applying strict hygienic rules }\end{array}$ & $\begin{array}{c}\text { Intra-company } \\
\text { measures }\end{array}$ & Insurance & $\begin{array}{c}\text { Collaboration OR } \\
\text { Production at } \\
\text { lowest cost }\end{array}$ & $\begin{array}{c}\text { Geographic dispersion OR } \\
\text { Business diversification }\end{array}$ \\
\hline & Relative risk attitude & 0.138 & 0.475 & 0.405 & 0.111 & 0.551 \\
\hline \multirow{3}{*}{ SER } & Farm features & & 0.215 & & & \\
\hline & Farm manager education & & & & & \\
\hline & Work experience & 0.287 & 0.218 & 0.065 & 0.172 & \\
\hline \multirow{10}{*}{ SR } & $\begin{array}{l}\text { Health safety OR Technology } \\
\text { availability }\end{array}$ & 0.272 & 0.262 & 0.431 & 0.218 & \\
\hline & Personal welfare & & & 0.320 & & 0.312 \\
\hline & Financial risk & & & & & \\
\hline & Environmental risk & 0.510 & 0.336 & & & \\
\hline & Market risk & & & & & \\
\hline & Social acceptance & & 0.289 & 0.216 & 0.371 & \\
\hline & Institutional & & 0.391 & & & \\
\hline & $\begin{array}{l}\text { Production cost \& Labor } \\
\text { availability }\end{array}$ & 0.287 & & & & \\
\hline & HABs & & & 0.242 & 0.240 & \\
\hline & Biofouling \& predators & & & & 0.328 & 0.306 \\
\hline
\end{tabular}


labor-intensive activity and requires a lot of physical work by a farmer, often under extreme weather conditions on a vessel. As most Greek mussel farms are micro-enterprises (Theodorou et al. 2014) and mussel farm owners are directly involved in the fieldwork, the health status of the operator and his family is a critical risk factor for business sustainability. Vessel availability (a suitable boat equipped with modern tools such as star wheels, French type grading machines, etc.) is the third major source of risk for mussel farming. Without these tools, it is very difficult for farmers to compete on the market and maintain production (Theodorou et al. 2011; Theodorou et al. 2015).

Bans on mussel harvesting due to harmful algal blooms (HABs) are also a major source of risk, as they prevent any marketing plans, especially during harvest periods (Theodorou et al. 2011, 2020). On the other hand, and unlike most sources of risk in fish aquaculture (Georgiadis et al. 2001; Murray \& Peeler 2005; Peeler et al. 2007), diseases are less important as a source of risk since there has never been any serious case of losses (Karagiannis \& Angelidis 2007; Karagiannis et al. 2013). Similar findings were reported by Ahsan and Roth (2010) for the emerging mussel sector in Denmark, which is a relatively new industry without any disease problem yet. The opposite situation is observed in France, where shellfish pathogens and summer mortality due to high temperatures have destroyed the sector's production several times (Huvet et al. 2010; Garcia et al. 2011; Pernet et al. 2012). Consequently, bivalve shellfish farmers assess sources of risk based on their own local experience.

Mussel transportation losses are also of low impact. Most Greek mussels are sold alive and it takes 1-3 days to deliver them to markets, including export markets (Angelidis 2007a; Theodorou et al. 2019). Nonetheless, these types of losses are limited and not considered catastrophic events.

Political pressure from non-governmental environmental groups on the sector is moderate, because operations are environmentally friendly and sustainable. However, when sites are located within Natura 2000 Protected Areas, new rules in legislation affecting the code of practice may introduce a future risk (Angelidis 2007b; Konstantinou et al. 2012; Latinopoulos et al. 2012; Karagiannis et al. 2013). Illegal actions against farms (i.e. poaching, destruction of installations) always carry a risk of loss, but so far this has been limited, representing isolated incidents and with manageable seasonal costs (not catastrophic). Sea rentals for this type of activity are affordable in the long term and not considered to be a significant risk.

\subsection{Perception of risk management strategies}

The most preferred response of Greek mussel farmers to a risk management strategy (with limited variability and standard deviation of $<1$ ) is to build up financial reserves to cope with unforeseen adversities in order to survive financially until the next season. Individual practices may include personal or family bank savings, a bank loan obtained through a long-term good business relationship, or keeping the farm in a good financial condition. Prioritizing liquidity and solvency is also considered very important by Danish mussel farmers (Ahsan \& Roth 2010). Certainty of their income from alternative sources, such as off-farm employment, is preferred as a risk mitigation strategy. Mussel farming is a seasonal activity and extra cash from other sources can cover possible losses due to "uncertain" production. Complementary work in different occupations offers some security by reducing overall income variability (Dickey \& Theodosiou 2006). These responses are not surprising, as pluri-activity and multiple job holding are structural features of farm households in Greece, and usually involve more household members than just the farmer (Kizos 2010; Kizos et al. 2011).

In Denmark, producing at the lowest possible cost is considered the primary risk management strategy (Ahsan \& Roth 2010). Although Greek mussel farmers do not have the strong cooperative mentality of Danish producers (Ahsan \& Roth 2010), they suggest that horizontal cooperation of farmers could mitigate losses, achieve benefits of scale, and reduce financial risk by lowering operating costs and increasing fixed capital depreciation (Cush \& Varley 2013; Theodorou et al. 2014). Finally, diversification seems to be the least priority for Greek mussel farmers, as their traditional background does not allow them to easily adopt novel technologies or open up to new markets. Furthermore, the limited suitable space available in Greece for new bivalve species, such as benthic clams or oysters, explains the limited preference for this strategy.

Among the strategies with moderate or very low impact, it is worth noting that private insurance policies are not a priority. Corporate structures, unlike farmers personally, wish to buy insurance as a common business policy because they can afford it.

However, Greek producers want to have insurance for their vessels and/or against the weather impact on mussel farm installations and equipment, and animal stock. French oyster farmers hold similar views on risk-transfer mechanisms (Le Bihan et al. 2013). They also support the request for specific customized hedging products for the European bivalve shellfish sector, as the market has so far failed to cover this "gap". 
Greek mussel farmers are reluctant to enter into agreements with wholesalers offering them long-term contracts with stable prices. This attitude can be attributed to: a) the unsuitability of these "modern tools" for the needs of the sector; b) the complicated structure and questionable reliability of these contracts; c) farmers' suspicion of modern business tools.

Greek mussel farmers suggested that bearable risks for them are those related to conventional self-protection mechanisms within the farm, as they feel familiar with their routine daily practices to prevent losses. This is consistent with their responses to the questionnaire, which show that they are accustomed to face risks in production and in general farming activities, making every effort to maximize income. It is a common attitude in agribusiness worldwide that farmers are confident in supervising their own production activities (Meuwissen et al. 2001; Le \& Cheong 2010).

The need for public compensation for the losses of Greek mussel farmers arises from causes of disasters that are not directly related to their activity. These may include irreversible phenomena or major unpredictable disasters due to weather conditions (e.g. tsunami, heat waves, anoxia, or radioactivity), extended harvest bans due to harmful algal blooms, pollution (e.g. oil spills), predator attacks (e.g. sea turtles), diseases, and illegal actions (e.g. sewage and radioactive waste discharges). Hanging parks are more prone to disasters compared to long lines, because they are located in shallow waters near estuaries.

There is currently no insurance policy for the Greek mussel farming sector, rendering the business exposed to operational risks (Theodorou et al. 2020; Theodorou \& Tzovenis 2021). At the European level, compensation is only available through the European Fisheries Fund in case of major disasters concerning the protection of livestock or human health. Through Article 57 of EU Regulation 508/2014, the EU further extends the scope of insurance compensation (covered by the European Maritime and Fisheries Fund) for aquaculture stock losses due to causes such as natural disasters, weather impacts, water quality, and diseases. At a global level, oil pollution losses could be covered by the International Oil Pollution Compensation (IOPC) fund (Le Bihan et al. 2013).

\subsection{Effect of socioeconomic behavior on the risk management strategies}

The socioeconomic profile of the farm/farmer has no influence on farmer' decisions. Mussel farming is a socially supported, local aquaculture activity in Greece that provides a supplementary income to coastal society members (Zanou et al. 2005). In addition, the sector is hampered in certain regions by the limited availability of locations with suitable environmental conditions for mussel growth, giving niche producers a competitive advantage. The latter attributes much of the sector's development to local governance, as most mussel farmers are local people (Latinopoulos et al. 2012; Konstantinou et al. 2012). People with a common cultural heritage convey unified perception across generations, thus limiting the scope for variation in mentality. Such shared beliefs tend to integrate with prevailing socioeconomic principles through either formal rules or informal norms of behavior (North 1993). Therefore, the relative risk attitude of mussel farmers significantly affects most of their risk management strategy choices, and their explained variation $\mathrm{R}^{2}$ is rather limited (between 0.21 and 0.58). Consequently, despite recognizing the market and financial risks as major sources of risk, they do not adopt a specific strategy to mitigate their effects.

The survey covering the period from November 2008 to February 2009 addressed mussel farmers' needs for risk-sharing strategies prior to the onset of the Greek financial crisis. The study is still relevant, but the current approach of farmers has to be investigated in the new business environment to identify the industry's adaptation and its likely new needs (Theodoridis et al. 2017; Theodorou \& Tzovenis 2017; Le Bihan et al. 2020; Avdelas et al. 2021; Lupo et al. 2021).

\section{Conclusions}

The following conclusions were drawn from the empirical work on the risk management strategies of Greek mussel farmers:

- Mussel farmers are more familiar with the risks associated with their day-to-day field work in production and marketing than with the financial issues involved.

- The major risk sources are related to the stagnation of ex-farm prices, to which farmers are unable to respond, and to their personal health status (the business is still labor intensive, any physical disability or health problem has a direct impact on farm management).

- Greek mussel farmers prefer to use financial credit reserves and the certainty of income from other sources as risk mitigation strategies.

- The demand for specific insurance services in the market, although recognized, still requires product customization. 
- Mussel farmers would like to purchase specific insurance policies for their operating vessels and for weather impacts.

- Unmanageable high impact/catastrophic risks such as major weather disasters, extended harvest bans due to HABs, pollution, predator attack, diseases and illegal activities should be covered by public funds.

- Mussel farmers insure their farms through good management practices under their own control.

- Risk management decisions are based on farmers' relative risk attitudes rather than their perception of risk sources.

\section{References}

Ahsan, D.A. \& Roth. E. (2010). Farmers' perceived risks and risk management strategies in an emerging mussel aquaculture industry in Denmark. Marine Resource Economics 25: 309-323. DOI: 10.5950/0738-1360-25.3.309.

Ahsan, D.A. (2011). Farmers motivations, risk perceptions and risk management strategies in a developing economy: Bangladesh experience. Journal of Risk Research 14(3): 325-349. DOI: 10.1080/13669877.2010.541558.

Angelidis, P. (2007a). Effects of storage temperature on oxygen depletion in intra-valve water and survival of the Mediterranean mussel Mytilus galloprovincialis LmK. Journal of Applied Ichthyology 23: 611-615. DOI: 10.1111/j.1439-0426.2007.01005.x.

Angelidis, P. (2007b). Shellfish culture in estuary zones and the sanitary restrictions. Scientific Annals of the Danube Delta Institute 13: 161-174.

Anderson, J.R. (2003). Risk in rural development: challenges for managers and policy makers. Agricultural Systems 75: 161-197.

Avdelas, L., Avdic-Mravlje, E., Borges Marques, A.C., Cano, S., Capelle, J.J. et al. (2021). The decline of mussel aquaculture in the European Union: Causes, economic impacts and opportunities. Reviews in Aquaculture 13(1): 91-118. DOI: 10.1111/raq.12465.

Batzios, C.H., Angelidis, P., Papapanagiotou, E.P., Moutopoulos, D.K., Anastasiadou, C.H. et al. (2004). Greek consumer's image of the cultured mussel market. Aquaculture International 12: 239-257.

Bergfjord, J.O. (2009). Risk perception and risk management in Norwegian aquaculture. Journal of Risk Research 12: 91-104. DOI: 10.1080/13669870802488941.

Bergfjord, O.J. (2013). Farming and risk attitude. Emirates Journal of Food \& Agriculture 25(7): 555-561. DOI: 10.9755/ ejfa.v25i7.13584.

Bondad-Reantaso, M.G., Arthur, J.R., \& Subasinghe, R.P. (Eds.) (2008). Understanding and applying risk analysis in aquaculture. In FAO Fisheries and Aquaculture Technical
Paper. No 519. Rome, FAO, 304 pp.

Cush, P., \& Varley, T. (2013). Cooperation as a survival strategy among west of Ireland small-scale mussel farmers. Maritime Studies 12: 11. DOI: 10.1186/2212-9790-12-11.

Dickey, H. \& Theodossiou, I. (2006). Who has two jobs and why? Evidence from rural coastal communities in West Scotland. Agricultural Economics 34: 291-301.

EU Regulation No 508/2014 (2014). Regulation of the European Parliament and the Council of 15 May 2014 on the European Maritime and Fisheries Fund and repealing Council Regulations (EC) No 2328/2003, (EC) No 861/2006, (EC) No 1198/2006 and (EC) No 791/2007 and Regulation (EU) No 1255/2011 of the European Parliament and of the Council. Official Journal of European Union L 140/66.

Fausti, S. \& Gillespie, J. (2006). Measuring risk attitude of agricultural producers using a mail survey: how consistent are the methods? Australian Journal of Agricultural Resource Economics 50(2): 171-188. DOI: 10.1111/j.14678489.2006.00328.x.

Filgueira, R., Comeaub, L.A., Landryb, T., Granta, J., Guyondetb, T. et al. (2014). Bivalve condition index as an indicator of aquaculture intensity: A meta-analysis. Ecological Indicators 39: 134-143. DOI: 10.1016/j.ecolind.2012.10.001.

Garcia, C., Thébault, A., Dégremont, L., Arzul, I., Miossec, L. et al. (2011). Ostreid herpesvirus 1 detection and relationship with Crassostrea gigas spat mortality in France between 1998 and 2006. Veterinary Research 42: 73. DOI: 10.1186/1297-9716-42-73.

Georgiadis, M.P., Gardner, I.A. \& Hedrick, R.P. (2001). The role of epidemiology in the prevention, diagnosis, and control of infectious diseases of fish. Preventive Veterinary Medicine 48: 287-302.

Greiner, R., Patterson, L. \& Miller, O. (2009). Motivations, risk perceptions and adoption of conservation practices by farmers. Agricultural Systems 99: 86-104.

Guillotreau, P., Allison, E.H., Bundy, A., Cooley, S.R., Defeo, O. et al. (2017). A comparative appraisal of the resilience of marine social-ecological systems to mass mortalities of bivalves. Ecology and Society 22(1): 46. DOI: 10.5751/ES09084-220146.

Guillotreau, P., Le Bihan, V., Morineau, B. \& Pardo, S. (2021). The vulnerability of shellfish farmers to HAB events: An optimal matching analysis of closure decrees. Harmful Algae 101: 101968. DOI: 10.1016/j.hal.2020.101968.

Hair, G.F, Anderson, R.E., Tatham, R.L., \& Black, W.C. (1998). Multivariate data analysis. Fifth Edition. Prentice-Hall International, Inc. 730 pp.

Hardaker, J.B., Huirne, R.B.M, Anderson, J.R. \& Lien, G. (2004). Coping with risk in agriculture. CABI Publishing, 2nd ed. 332 pp.

Hardaker, J.B., Lien, G., Anderson, J.R. \& Huirne, R.M.B. (2015). Coping with Risk in Agriculture: Applied Decision Analysis. Wallingford. CABI.10.1079/9781780645742.0000

Huirne, R.B.M., Meuwissen, M.P.M., Hardaker, J.B. \& Anderson, 
J.R.(2000). Risk and risk management in agriculture: an overview and empirical results. International Journal of Risk Assessment Management 1: 125-136. DOI: 10.1504/ IJRAM.2000.001491.

Huirne, R.B.M., Meuwissen, M.P.M. \& Van Asseldonk, M.A.P.M. (2007). Importance of whole-farm risk management in agriculture. In Handbook of Operations Research in Natural Resources. Springer Publ. (pp. 7-15).

Huvet, A., Normand, J,, Fleury, E., Quillien, V., Fabioux, C. et al. (2010). Reproductive effort of Pacific oysters: a trait associated with susceptibility to summer mortality. Aquaculture 304: 95-99.

Joffre, O.M., Klerkx, L. \& Khoa, T.N.D. (2018a). Aquaculture innovation system analysis of transition to sustainable intensification in shrimp farming. Agronomy. Sustainable Development 38(3): 1-11.

Joffre, O.M., Poortvliet, P.M., \& Klerkx, L. (2018b). Are shrimp farmers actual gamblers? An analysis of risk perception and risk management behaviors among shrimp farmers in the Mekong Delta. Aquaculture 495: 528-537.

Joffre, O.M., Poortvliet, P.M., \& Klerkx, L. (2019). To cluster or not to cluster farmers? Influences on network interactions, risk perceptions, and adoption of aquaculture practices. Agricultural Systems 173: 151-160.

Kahneman, D. \&Tversky, A. (1979). Prospect theory: An analysis of decision under risk. Econometrica 47: 263-291.

Karagiannis, D. \& Angelidis, P. (2007). Infection of cultured mussels Mytilus galloprovincialis by the protozoan Marteilia sp. In the Thermaikos Gulf (N Greece). Bulletin of European Association of Fish Pathologists 27: 131-141.

Karagiannis, D., Vatsos, I.N., Theodoridis, A.\&Angelidis, P. (2013). Effect of culture system on the prevalence of parasites of the Mediterranean mussel Mytilus galloprovincialis (Lamark, 1819). Journal of Hellenic Veterinary Medicine Society 64(2): 113-122.

Kizos, T.(2010). Multifunctionality of farm households in Greece. Norwegian. Journal of Geography 64(2): 105-116. DOI: $10.1080 / 00291951.2010 .481137$.

Kizos. T., Marin-Guirao, J.I., Georgiadi, M.E., Dimoula, S., Karatsolis, E. et al. (2011). Survival strategies of farm households and multifunctional farms in Greece. The Geographical Journal 177: 335-346. DOI: 10.1111/j.14754959.2011.00403.x.

Konstantinou, Z.I., Krestenitis, Y.N., Latinopoulos, D., Pagou, K., Galinou-Mitsoudi, S. et al. (2012). Aspects of musselfarming activity in Chalastra, Thermaikos Gulf, Greece: an effort to untie a management Gordian Knot. Ecology and Society 17(1): 1. DOI: 10.5751/ES-04455-170101.

Latinopoulos, D., Konstantinou, Z. \& Krestenitis, Y. (2012). Simulation and multicriteria analysis in sustainable coastal planning: The case of aquaculture in Thermaikos Gulf, Greece. Environmental Development Sustainability 14(6): 1027-1045.

Le Grel, L. \& Le Bihan, V. (2009). Oyster farming and externalities:
The experience of the Bay of Bourgneuf. Aquaculture Economics \& Management 13: 112-123.

Le Bihan, V., Pardo, S. \& Guillotreau, P. (2013). Risk perception and risk management strategies of oyster farmers. Marine Resource Economics 28(3): 285-304. DOI: 10.5950/07381360-28.3.285.

Le Bihan, V., Catalo, M. \& Le Bihan, J. (2020). Reorganization of the value chain activities of oyster companies on the Atlantic coast following health crises in France (2006-2013). Marine Policy 117. DOI: 10.1016/j.marpol.2018.05.013.

Le, T.C., \& Cheong, F. (2010). Perceptions of risk and risk management in Vietnamese catfish farming: an empirical study. Aquaculture Economics \& Management 14: 282-314. DOI: 10.1080/13657305.2010.526019.

Lien, G., Flaten, O., Jervell, A.M., Ebbesvik, M., Koesling, M. et al. (2006). Management and Risk Characteristics of Part-Time and Full-Time Farmers in Norway. Reviews in Agricultural Economics 28(1): 111-131. DOI: 10.1111/j.14679353.2006.00276.x.

Lupo, C., Bougeard, S., Le Bihan, V., Blin, J.L., Allain, G. et al. (2021). Mortality of marine mussels Mytilus edulis and M. galloprovincialis: Systematic literature review of risk factors and recommendations for future research. Reviews in Aquaculture 13(1): 504-536.

MacCrimmon, K.R. \& Wehrung, D.A. (1986). Taking risks: The management of uncertainty. New York: Macmillan.

Meuwissen, M.P.M., Huirne, R.B.M. \& Hardaker, J.B. (2001). Risk and risk management: an empirical analysis of Dutch livestock farmers. Living Production Science 69: 43-53. DOI: 10.1016/S0301-6226(00)00247-5.

Murray, A.G. \& Peeler, E.J. (2005). A framework for understanding the potential for emerging diseases in aquaculture. Preventive Veterinary Medicine 67: 223-235. DOI: 10.1016/j.prevetmed.2004.10.012.

Nguyen, T.T. (2012a). Implicit price of mussel characteristics in the auction market. Aquaculture International 20: 605-618. DOI: 10.1007/s10499-011-9489-x.

Nguyen, T.T. (2012b). An Inverse Almost Ideal Demand System for Mussels in Europe. Marine Resource Economics 27: 149164. DOI: 10.5950/0738-1360-27.2.149.

North, D.C. (1993). Prize Lecture: Economic Performance through Time. Nobelprize.org. Nobel Media AB 2014. http://www.nobelprize.org/nobel_prizes/economicsciences/laureates/1993/north-lecture.html

Patrick, G.F. \& Musser, W.N. (1997). Sources of and responses to risk: Factor analyses of large-scale US corn belt farmers. In R. Huirne, J.B. Hardaker \& A.A. Dijkhuizen (Eds.), Risk management strategies in agriculture: State of the art and future perspectives. Mansholt studies 7: 45-53. Wageningen: Wageningen Agricultural University.

Peeler, E.J., Murray, A.G., Thebault, A., Brun, E., Giovaninni, A. et al. (2007). The application of risk analysis in aquatic animal health management. Preventive Veterinary Medicine 81: 3-20. DOI: 10.1016/j.prevetmed.2007.04.012. 
Pernet, F., Barret, J., Le Gall, P., Corporeau, C., Dégremont, L. et al. (2012). Mass mortalities of Pacific oysters Crassostrea gigas reflect infectious diseases and vary with farming practices in the Mediterranean Thau lagoon, France. Aquaculture Environmental Interactions 2: 215-237. DOI: 10.3354/aei00041.

Rabin, M. \& Thaler, R. (2001). Anomalies: Risk Aversion. Journal of Economic Perceptions 15: 219-232.

Stensland, S. (2013). Landowners' Perception of Risk Sources and Risk Management Strategies in Norwegian Salmon Angling Tourism. Scandinavian Journal of Hospitality \& Tourism 13(3): 208-227. DOI: 10.1080/15022250.2013.830362.

Rodrigues, L.C., van den Bergh, J.C.J.M., Massa, F., Theodorou, J.A. et al. (2015). Sensitivity of Mediterranean Bivalve Mollusc Aquaculture to Climate Change and Ocean Acidification: Results from a producers' survey. Journal of Shellfish Research 34(3): 1161-1176. DOI: 10.2983/035.034.0341.

Theodoridis, A., Batzios, C., Ragkos, A. \& Angelidis, P. (2017). Technical efficiency measurement of mussel aquaculture in Greece. Aquaculture International 25(3): 1025-1037. DOI: 10.1007/s10499-016-0092-z.

Theodorou, J.A. \& Tzovenis, I. (2004). Aquaculture Insurance. In J. Teugels \& B. Sundt (Eds.), Encyclopedia of Actuarial Sciences (Vol. I, pp. 86-90). J. Willey and Sons Publications.

Theodorou, J.A., Viaene, J, Sorgeloos, P. \& Tzovenis, I. (2011). Production and Marketing Trends of the cultured Mediterranean mussel Mytilus galloprovincialis L. 1819, in Greece. Journal of Shellfish Research 30(3): 1-16. DOI: 10.2983/035.030.0327.

Theodorou, J.A., Tzovenis, I, Adams, C.M., Sorgeloos, P. \& Viaene, J. (2014). Risk factors affecting the profitability of the Mediterranean mussel Mytilus galloprovincialis Lamarck 1819, farming in Greece. Journal of Shellfish Research 33(3): 695-708. DOI: 10.2983/035.033.0304.

Theodorou, J.A., Perdikaris, C. \& Filippopoulos, N.G. (2015). Evolution Through Innovation in Aquaculture: The Case of the Greek Mariculture Industry. Journal of Applied Aquaculture 27: 1-22. DOl: 10.1080/10454438.2015.1049473.

Theodorou, J.A., Leech, B.S., Perdikaris, C., Hellio, C. \& Katselis, G. (2019). Performance of the cultured Mediterranean mussel Mytilus galloprovincialis Lamark 1819, after summer post-harvest re-immersion. Turkish Journal of Fisheries \& Aquatic Science. DOI: 10.4194/1303-2712-v19_03_05.

Theodorou, J.A., Moutopoulos, D.K. \& Tzovenis, I. (2020). Semi-quantitative risk assessment of Mediterranean mussel (Mytilus galloprovincialis L.) harvesting bans due to harmful algal bloom (HAB) incidents in Greece. Aquaculture Economics \& Management. DOI: 10.1080/13657305.2019.1708994.

Theodorou J.A. \& Tzovenis I. (2021). A framework for risk analysis of the shellfish aquaculture: The case of the
Mediterranean mussel farming in Greece. Aquaculture \& Fisheries. DOI: 10.1016/j.aaf.2021.04.002.

Thong, N.T. (2012). An Inverse Almost Ideal Demand System for Mussels in Europe. Marine Resource Economics 27: 149164. DOI: 10.5950/0738-1360-27.2.149.

Tveterås, R. (1999). Production Risk and Productivity Growth: Some Findings for Norwegian Salmon Aquaculture. Journal of Production Analysis 12(2): 161-179. DOI: 10.1023/A:1007863314751.

van Raaij, W.F. (1981). Economic Psychology. Journal of Economic Psychology 1: 1-24. DOI: 10.1016/01674870(81)90002-7.

vanWinsen, F., de Mey, Y., Lauwers, L., Van Passel, S., Vancauteren, M. et al. (2013). Cognitive mapping: A method to elucidate and present farmers' risk Perception. Agricultural Systems 122: 42-52. DOI: 10.1016/j.agsy.2013.08.003.

van Winsen, F., de Meyc, Y., Lauwers, L., Van Passelc, S., Vancauterend, M. et al. (2016). Determinants of risk behaviour: effects of perceived risks and risk attitude on farmer's adoption of risk management strategies. Journal of Risk Research 19(1): 56-78. DOI: 10.1080/13669877.2014.940597.

Wauters, E., van Winsen, F., de Mey, Y. \& Lauwers, L. (2014). Risk perception, attitudes towards risk and risk management: evidence and implications. Agricultural Economics - Czech 60(9): 389-405.

Wright, S. (1934). The Method of Path Coefficients. Ann. Math. Statist. 5(3): 161-215. DOI: 10.1214/aoms/1177732676.

Zagmutt, F.J., Sempier, S.H. \& Hanson, T.R. (2013). Disease Spread Models to Estimate Highly Uncertain Emerging Diseases Losses for Animal Agriculture Insurance Policies: An Application to the U.S. Farm-Raised Catfish Industry. Risk Analysis 33(10): 1924-1937. DOI: 10.1111/risa.12038.

Zanou, B., Anagnostou, Ch. \& Papathanassiou, E. (2005). Seeking the factors to stimulate the users in the coastal zones planning. Case study: Open discussions with mussel farmers in the Axios river (GR). Mediterranean Marine Science 6/1: 107-115. DOI: 10.12681/mms.197. 